\title{
早期膀胱癌の浸潤に関する臨床的および実験的研究
}

\author{
岡山大学医学部泌尿器科教室 \\ (主任：新島端夫教授) \\ 松 元 鉄 二*

\section{CLINICAL AND EXPERIMENTAL STUDIES ON INFILTRATION OF EARLY URINARY BLADDER CARCINOMA}

\author{
Tetsuji Matsumoto \\ Department of Urology, University of Okayama, School of Medicine, Okayama \\ (Director: Prof. T. Niijima)
}

Results of treatment were studied in cases of early stage cancer of the urinary bladder, and some expermental studies were performed in which Brown-Pearce tumors were inoculated into vesical walls of rabbits to produce experimental tumors for clinical evaluation of early bladder cancer on the basis of types of growth and tumor cell.

1) During the 20-year period, 152 cases of early stage cancer of the urinary bladder were treated with fulguration and partial cystectomy in our hospital and fulguration group was better than the other on a 5-year survival rate.

2) Types of growth and tumor cell seem to be important for overall clinical evaluation on early stage cancer of urinary bladder.

3) Growth of early stage cancer of the urinary bladder are classified into 4 types; P (papillary type), $\mathrm{S}$ (surround type), $\mathrm{W}$ (wide type) and I (infiltrate type).

$\mathrm{P}$ and $\mathrm{S}$ types represented true low grade and low stage, while $\mathrm{W}$ and $\mathrm{I}$ type indicated poor prognosis in spite of early stage.

4) Brown-Pearce tumor was transplanted experimentally into the vesical wall (vertex and trigonum) for the production of the protruding tumor in the vesical cavity.

5) Implanted tumors resembling early clinical cancer of the bladder were obtained one or two weeks after the submucosal inoculation in the vesical wall.

These tumors had a low stage frequently due to the resistance of muscle layer in spite of high grade in the cell type.

In the group inoculated into deep muscle layer, a rapid progress to the infiltrative type was indicated.

6) Cystoscopic growth form of tumor and grading of the tumor cell by biopsy are important for the selection of therapeutic method in early bladder cancer.

\section{I 緒 言}

膀胱癌の治療法は, 過去幾多の研究が根強く続けられ て来たにもかかわらず，その治療成績は，今日に执いて も必ずしも良好とは云兄ない。ことに当然根治性を期待 しうる筈の早期癌に拈いてすら, 他の臟器癌の气れに比 して決して満足すべき成績ではない。それは膀胱癌が他 臓器癌とまつたく趣を異にして, しばしば不可抗力的な 再発を招来する特異性があるからである。したがつて膀 胱癌の臨床的研究は，早期に発見し，如何にして再発を

\footnotetext{
*助手
}

防止するかが，ひとつの大きな山と考元られるすすねわ ち現状での膀胱癌の研究は, この再発の問題を中心に, いまや足踏みないし再出発の段階にあると思われる。今 日, 内外飞和けるこの分野での研究は, この再発, さら には上り根本的な発癌機棈の検討にまでさかのぼり種々 な観点からの興味ある報告があい次いでいる。すなわら 発癌物質の解明およびその抑制, 癌細胞の組織培養ない 乙電子顕微鏡的研究, 癌細胞に陰ぺいされた造腫瘍因子 の求明。あるいは腫瘍免疫学的研究など多角的な研究手 段が新しく開拓されつつあり，輝かしい成果が期待され 
るところであるが，ここにおいてわれわれが今一度反省 し, 留意すべきことは, かかる研究を推進する場合, や やもすれば，癌の基盤となる増殖形態像の違つた病巣を 単一化して, 単なる癌の概念の中に一括総合し研究資料 の対象とせんとする危険性のあることである。すなわち 膀胱癌組織を構成する腫瘍細胞自体の立場にかえつてそ の正確な基本的增殖体系を明膫にしておくことが，多角 的研究の基盤として不可欠である. かくて統一された病 理組織学的基本形態像の礎定の上に，種々綿密に立案計 画された立体的な研究が積みあげられてこそ，誤りのな い発展の道が開かれるものと考学る。

当教室に和いては，さきに大村ら ${ }^{12)}$ (1962，1964） がこの点に着目して, 初期の膀胱粘膜の增殖によつて累 積した上皮細胞層内に見られる前癌状態の存在，ひい てはその臨床経過につれての癌化過程を追跡し, 報告し た。 また松村)（1967）は, ${ }^{3} \mathrm{H}$-Thymidine によつて, かかる早期癌の癌化過程に和ける腫瘍細胞核 D.N.A. の変動を検討し, 初期病像と予後との関係を追求報告し た. また大北 ${ }^{5(6) 7)}$ は第55回日本泌尿器科学会総会招よび 第18回西日本連合地方会の膀胱癌シンポジアムで，早期 癌の病像と治療成績から今後の治療方法の選択的あり方 を論述した．以上のごとき一連の研究からみても一見い かにも単純で等閉視されがちな $\left(W i l l i s^{8)} 1967\right)$ 膀胱癌 の病理形態像も，詳細に観察追求するとき意外に検討に 值する興味ある事実のあることが遂次明らかとなつた。

膀胱癌の病像については, 最近臨床的予後との関係に 招いて, grade と stage, 特に stage が重視される傾向 は強いが，以上の観点から私は早期癌を対象に今一度特 に grade に重点を物いてその臨床的意義を検討せんと 企てた。すなわち教室の早期癌の治療成績に検討を加 え, また早期癌の初期病像をあらたに腫瘍発育形式の面 で分析を行なつて，従来単に腫㕫細胞型のみに立脚した grade と stage の関係に検討を加えてみた。 また同時に 可移植性の Brown-Pearce 腫汮を家鬼膀胱壁に移植し $\tau$, 実験的膀胱腫瘍を作り，人膀胱癌の low grade $飞$ 近似した実験を試み，検索を行なつたところ，早期癌に おける gradeが, stage の判定の上で重要な意義を有す ることを裏付ける成績を得たので，ここに報告する。

\section{II 早期膀胱癌の術後成績と初期病像の臨床}

a) 研究対象抒よび研究方法

教室に括ける1947年より1966月末までの過去20年間の 原発性膀胱癌入院患者数は 617 例で，この内手術患者数 は, 電気焼灼術 193例, 膀胱部分切除術 135例, 膀胱全剔
除術十尿管皮膚㾇62例, 総計 390例であるが, 前述した ごとく, 私の研究主題は, 早期癌 (膀胱の早期癌の解釈 は区々であるが，この場合腫瘍の大きさが囿指頭大まで で, 数は単発ないし 3 ケ以内の初発限局性病巣で, 病理 組織学的には grade II, stage $B_{1}$ までに限定する) の再 検討を目的とするので，その対象はおのづから全剔除術 施行例を除外した電気焼灼術および部分切除術施行症例 の中から選択されるわけで，結局術後経過および予後の 明らかな電気焼灼術80例と部分切除術72例計 152例であ る。また治療成績の検討は 5 年生存率で求めた。 5 年 生存率は,すへて術後満 5 力年を完全に経過 した追跡 可能な1961月末 までの症例のみを対象とし，それを穾 数で調査した上での実測生存率（以下生存率と記す）で 示すことにした。 5 年生存率については，1963年 9 月の International symposium on end results of cancer therapy ${ }^{910) 11)}$ で公示された相対生存率 (relative survival rate) によることも考兄られるが，生存率の算定 飞招いて，しばしば問題のある，1）追跡不能例，2） 観察期間中で統計期間に満たない場合，3）死因が本来 の疾患以外の場合などの取扱いについて種々難点のある ことなどからこれらを除外する意味で今回は実測生存 率を求めたのである.

研究方法は各症例について, 初診時の膀脱鏡所見を重 視確認した上で，それを基に術前の生検材料あるいは剔 出材料について, 綿密な臨床病理組織学的所見を組み合 せ検討した. grade は American bladder tumor registry ${ }^{12)}$ の規定により，また一方 stage は Jewett ${ }^{13144)}$ の分 類とは別に，最近重視されつつある. U.I.C.C ${ }^{15) 1617)}$. の T.N.M 分類法に準拠して分類した。な 類では， stage に特ける Jewett のOが $\mathrm{T}_{1}$ に含まれる ことになつて, 幾分主題の事項について緻密さを欠く拉 それがあるので，良性乳頭腫およびそれに随伴する上皮 内癌 (Carcinoma in situ) を一括して, I.S. として $\mathrm{T}_{1}$ と区分することにした，そしてそれぞれの分類のも とに grade および stage 別にまた電気焼灼術，部分 切除術の術式別に治療成績を検討した。

一方これらの早期癌の観察過程中に, 初期病像として 確認出来た早期の病巣について，単に従来の腫瘍細胞型 のみではなく, 将来進展しうる腫瘍発育形式を予測加味 して, grade を判定し得る分類法を検討し，その所見に もとずいて新な分類を試み，同時にその早期癌の分類に 従つて，施行された電気焼灼術の術後成績に検討を加兄 た. 而して膀胱粘膜上皮細胞に最初にあらわれた変化に 
ついても，従来のごとく単に Hyperplasia として，簡 単に一律に考学ることが妥当であるか否か追求すること とした。

\section{b) 研究成績}

1）電気焼灼術の治療成績

総数 80 例の術後 5 月生存率は, grade と生存率では (第 1 表)，良性乳頭腫（pap）拈よび I 度乳頭状癌で

第 1 表 電気焼灼術, 分化度と生存率 (80例)

\begin{tabular}{|c|c|c|c|c|c|c|}
\hline 分化度 & 例数 & 1 年 & 2 年 & 3 年 & 4 年 & 5 年 \\
\hline Pap + I & 26 & 26 & $\begin{array}{r}24 \\
92.30\end{array}$ & $\begin{array}{r}23 \\
88.40\end{array}$ & $\begin{array}{c}22 \\
84.6 \%\end{array}$ & $80.7 \%$ \\
\hline II & 25 & $96^{24} \%$ & $88^{22}$ & $88^{22}$ & $84^{21}$ & $76^{19}$ \\
\hline 小 計 & 51 & $98^{50}$ & $\begin{array}{r}46 \\
90.1 \\
\end{array}$ & $\begin{array}{r}45 \\
88.2 \\
\end{array}$ & $\begin{array}{r}43 \\
84.3 \\
\end{array}$ & $\begin{array}{r}40 \\
78.4 \\
\end{array}$ \\
\hline III $+U$ & 18 & $\begin{array}{r}17 \\
94.4\end{array}$ & $\begin{array}{r}15 \\
83.3 \\
\end{array}$ & $\begin{array}{r}11 \\
66.6\end{array}$ & $\begin{array}{r}10 \\
55.5\end{array}$ & $\begin{array}{r}9 \\
50.0 \\
\end{array}$ \\
\hline IV & 11 & $\begin{array}{r}10 \\
90.9 \\
\end{array}$ & $\begin{array}{r}7 \\
63.6 \\
\end{array}$ & $\begin{array}{r}5 \\
45.4 \\
\end{array}$ & $\begin{array}{r}4 \\
36.5\end{array}$ & $\begin{array}{r}2 \\
18.7 \\
\end{array}$ \\
\hline 計 & 80 & $95^{76}$ & ${ }^{6}{ }^{68}$ & $\begin{array}{r}62 \\
77.5 \\
\end{array}$ & $\begin{array}{r}57 \\
71.2 \\
\end{array}$ & $\begin{array}{r}51 \\
63.7 \\
\end{array}$ \\
\hline
\end{tabular}

(岡山大学)

21/26 (80.7\%)， II 度は19/25 (76.0\%) となり，本研究 の目標である早期癌 の小計は40/51（78.4\%）である.

一方浸潤癌はもちろん電気焼灼術の適応ではないが，全 身状態，合併症などの兼合い上，止むなく施行した症例

（この内生検で grade が不明な例は unknown（U）と して四度に加えて分類した。）正度十Uについてみると 9/18(50.0\%)で，さらにIV度ともなると $2 / 11(18.7 \%)$ の”生存率を示して和り，結局電気焼灼術全例 80 例の grade による 5 年生存率は $51 / 80$ (63.7\%) となる。

stage と生存率では (第 2 表)，I.S. + $\mathrm{T}_{1}$ では 30/36 (83.3\%), $\mathrm{T}_{2}$ では $17 / 25$ (68.0\%) で早期癌の小計は

第 2 表 電気狫灼術. 浸潤度と生存率

\begin{tabular}{|c|c|c|c|c|c|c|}
\hline 浸潤度 年数 & 例数 & 1 年 & 2 年 & 3 年 & 4 年 & 5 年 \\
\hline $\mathrm{I} . \mathrm{S}+\mathrm{T}_{1}$ & 36 & 36 & $91.6 \%$ & $\begin{array}{r}32 \\
88.8\end{array}$ & $\begin{array}{r}31 \\
86.1 \\
\end{array}$ & $\begin{array}{r}30 \\
83.3\end{array}$ \\
\hline $\mathrm{T}_{2}$ & 25 & $\begin{array}{c}24 \\
96.0 \%\end{array}$ & $\begin{array}{r}23 \\
92.0 \\
\end{array}$ & $\begin{array}{r}20 \\
80.0\end{array}$ & $\begin{array}{r}19 \\
76.0\end{array}$ & $\begin{array}{r}17 \\
68.0\end{array}$ \\
\hline 小 計 & 61 & $\begin{array}{r}60 \\
98.3\end{array}$ & $\begin{array}{r}56 \\
91.6\end{array}$ & $\begin{array}{r}52 \\
85.2 \\
\end{array}$ & $\begin{array}{r}50 \\
81.9\end{array}$ & $\begin{array}{r}47 \\
77.0\end{array}$ \\
\hline $\mathrm{T}_{3}$ & 13 & $\begin{array}{r}11 \\
84.6\end{array}$ & $\begin{array}{r}8 \\
61.5\end{array}$ & $\begin{array}{r}8 \\
61.5\end{array}$ & $\begin{array}{r}7 \\
53.8\end{array}$ & $\begin{array}{r}4 \\
30.7\end{array}$ \\
\hline $\mathrm{T}_{4}$ & 6 & $\begin{array}{r}5 \\
83.3\end{array}$ & 66.6 & $\begin{array}{r}2 \\
33.3\end{array}$ & 0 & 0 \\
\hline 計 & 80 & $\begin{array}{r}76 \\
95.0\end{array}$ & $\begin{array}{r}68 \\
85.0 \\
8\end{array}$ & $\begin{array}{r}62 \\
77.5 \\
\end{array}$ & $\begin{array}{r}57 \\
71.2\end{array}$ & $\begin{array}{r}51 \\
63.7\end{array}$ \\
\hline
\end{tabular}

(岡山大学)
47/61 (77.0\%) となり，浸潤癌の $\mathrm{T}_{3}$ では $4 / 13(30.7$ $\%), \mathrm{T}_{4}$ では 5 年生存例はない。

2）膀胱部分切除術の治療成績

総数72例の生存率は, grade 別にみると（第 3 表),良

第 3 表 部分切除術. 分化度と生存率（7例）

\begin{tabular}{|c|c|c|c|c|c|c|}
\hline 分化度 & 例数 & 1 年 & 2 年 & 3 年 & 4 年 & 5 年 \\
\hline$P a p+I$ & 15 & 15 & 14 & $80 \%$ & 10 & 10 \\
\hline II & 18 & $\begin{array}{c}15 \\
83.3 \%\end{array}$ & $\begin{array}{r}13 \\
72.2\end{array}$ & $\begin{array}{r}11 \\
61.1\end{array}$ & $50^{9}$ & $\begin{array}{r}8 \\
44.4\end{array}$ \\
\hline 小 計 & 33 & $\begin{array}{r}30 \\
90.9\end{array}$ & $\begin{array}{r}27 \\
82.4\end{array}$ & $\begin{array}{r}23 \\
69.6\end{array}$ & $\begin{array}{r}19 \\
57.6\end{array}$ & $\begin{array}{r}18 \\
54.5\end{array}$ \\
\hline III & 27 & $\begin{array}{r}23 \\
85.2 \\
\end{array}$ & $\begin{array}{r}19 \\
70.4\end{array}$ & $\begin{array}{r}13 \\
48.1\end{array}$ & $\begin{array}{r}9 \\
33.3\end{array}$ & $\begin{array}{r}8 \\
29.6\end{array}$ \\
\hline IV & 12 & $75^{9}$ & $\begin{array}{r}7 \\
58.3\end{array}$ & $\begin{array}{r}5 \\
41.6\end{array}$ & $25^{3}$ & \\
\hline 計 & 72 & $\begin{array}{r}62 \\
86.1\end{array}$ & $\begin{array}{r}53 \\
73.6 \\
\end{array}$ & $\begin{array}{r}41 \\
56.9 \\
\end{array}$ & $43^{31}$ & $\begin{array}{r}29 \\
40.2 \\
\end{array}$ \\
\hline
\end{tabular}

(岡山大学)

性乳頭腫㧍よび I 度乳頭状癌で， $10 / 15(66.6 \%)$, II 度 では 8/18 (44.4\%), 早期癌の小計は18/33 (54.5\%) と なる。一方浸潤癌は度で $8 / 27(29.6 \%)$, IV 度で $3 / 12$ $(25.0 \%)$, 結局部分切除術全例72例の 5 年生存率は $29 / 72$ (40.2\%) である.

stage と生存率の関係をみると（第 4 表）, I.S。 $+T_{1}$

第 4 表 部分切除術. 浸潤度と生存率

\begin{tabular}{|c|c|c|c|c|c|c|}
\hline $\begin{array}{c}\text { 年数 } \\
\text { 浸潤度 }\end{array}$ & 例数 & 1 年 & 2 年 & 3 年 & 4 年 & 5 年 \\
\hline $\mathrm{I} . \mathrm{S}+\mathrm{T}_{1}$ & 17 & 17 & $\begin{array}{c}15 \\
88.2 \%\end{array}$ & $\begin{array}{r}13 \\
76.4\end{array}$ & $\begin{array}{r}11 \\
64.7\end{array}$ & $\begin{array}{r}10 \\
58.8\end{array}$ \\
\hline $\mathrm{T}_{2}$ & 23 & 21 & $\begin{array}{r}19 \\
82.6\end{array}$ & $\begin{array}{r}15 \\
65.2\end{array}$ & $\begin{array}{r}12 \\
52.1\end{array}$ & $\begin{array}{r}12 \\
52.1 \\
\end{array}$ \\
\hline 小 計 & 40 & $\begin{array}{r}38 \\
95.0\end{array}$ & $\begin{array}{r}34 \\
85.0\end{array}$ & $\begin{array}{r}28 \\
70.0 \\
\end{array}$ & $\begin{array}{r}23 \\
57.5 \\
\end{array}$ & $\begin{array}{r}22 \\
55.0 \\
\end{array}$ \\
\hline $\mathrm{T}_{3}$ & 20 & $\begin{array}{r}15 \\
75.0 \\
\end{array}$ & $\begin{array}{r}13 \\
65.0 \\
\end{array}$ & $\begin{array}{r}9 \\
45.0 \\
\end{array}$ & $\begin{array}{r}6 \\
30.0 \\
\end{array}$ & $\begin{array}{r}5 \\
25.0 \\
\end{array}$ \\
\hline $\mathrm{T}_{4}$ & 12 & $\begin{array}{r}9 \\
75.0 \\
\end{array}$ & $\begin{array}{r}6 \\
49.8 \\
\end{array}$ & $\begin{array}{r}4 \\
23.2 \\
\end{array}$ & $\begin{array}{r}2 \\
16.6 \\
\end{array}$ & $\begin{array}{r}2 \\
16.6 \\
\end{array}$ \\
\hline 計 & 72 & $\begin{array}{r}62 \\
86.1\end{array}$ & $\begin{array}{r}53 \\
73.6\end{array}$ & $\begin{array}{r}41 \\
56.9\end{array}$ & $\begin{array}{r}31 \\
43.0 \\
\end{array}$ & $\begin{array}{r}29 \\
40.2 \\
\end{array}$ \\
\hline
\end{tabular}

(岡山大学)

は10/17 (58.8\%), $\mathrm{T}_{2}$ では12/23（52.1\%）となりしたが つて早期癌の小計は $22 / 40(55.0 \%)$ である。一方浸㵎 癌では $\mathrm{T}_{3}$ で $5 / 20$ (25.0\%), $\mathrm{T}_{4}$ では $2 / 12(16.6 \%)$

であつた。

3）治療成績の小括

以上の成績から早期癌の電気焼灼術と部分切除術の 5 年生存率を比較すれば, grade では電気焼昫術が78.4 
\%, 部分切除術では $54.5 \%$ となり, stage 別では, 電気 焼灼術で $77.0 \%$ ，部分切除術では $55.0 \%$ となる。この浅 表浸潤例の両術式の治療成績の差は，それぞれの適応に よつて，自ら異つた成績を示するので，相対比すること 自体，大い腬盾がある。しかし教室における1955年以 降は, 当時の積極的剔除術の趨勢に従つて,たとえ早期の 癌においても, “広沉な部分切除術は最良の治療なり” の基本方針に基き積極的な部分切除術を選択した時代で あつて, あわよくば早期膀胱癌の完全な根治性を確立し 得るとの期待をかけた時代でもあり，この頃両術式の例 数が注が同数に見られた所以である。したがつて，今 回の両術式の比較は, かかる意味でははなはだ意義のあ る貴重な資料とみることが出来よう。而して早期癌での 両術式の比較に扔いて, 部分切除術が低率を示したこと は, 早期癌に怙汀る部分切除術の根治性に対する期待が 破れた成績とも云えるのである。すなわち膀胼癌の治療 に際してな抹末解決ないわゆる不可抗力とも云われる再 発の問題も考慮するとき，少くとも初期癌の段階におい ては, 最初の治療法として先ず患者に最も手術侵襲の少 い術式を選ぶのが良策であることを示唆する成績であつ た.

早期癌の範囲内に限定して，それぞれのgrade と stage が如何に関係するかをみると, grade で分類した治療 と, stage で分類した治療成績と, stage で分類した成 績とでは，両術式の間で大差がない。この結果は初期癌 に関する限り, 従来膀胱癌の予後に関係して強調されて 来た stageを grade より重視すべきであるとする考兄 方に再考をらながす資料となろう. 事実 stage の重要性 は周知のことでもあり，正確に把握された stage に立脚 することは理想的なことではあるが，さてわれわれの日 常臨床面でいざ早期癌に直面した場合, 決して stage がそれ程簡単に決定しうるものではない。一方綿密な膀 胱鏡所見をもとにして生検をすれば，ほとんどの症例で 腫瘍の組織所見を得ることが出来るし，実際にはこの生 検資料について, grade を求め, 早急に治療対策をたてら れる症例が大部分である。しかし生検資料による grade の判定法も必ずしも簡単ではなく，従来の腫瘍細胞型の みでは，誤診の多いことも指摘されている。そこでこれ を改善するために，膀脱鏡所見と共に，これから類推さ れる腫瘍発育型式をも加味し, 純臨床病理学的な立場に 基いて新な基準を設け，とれがより正確な判定法となる か否か検討せんと試みた。

4)早期膀胱癌の初期病像に対する臨床病理学的分類法 私案
上述のごとき治療成績から，早期癌の治療対策として 保存的な電気焼灼術か，積極的な切除を施すべきか（全 剔除術までを含めて), 適応の決定がまず問題となる。こ れを生検で得た初期嗹瘍像で決め得ればすことに好都合 である．さきに大村ら ${ }^{12)}$ (1962，1964）は，膀脱乳頭 腫之前癌状態との関係, 上皮内癌の癌化過程, さらには 初期病像からの将来への予後推測について報告したが, 私は今回, Melicow (1955 $\left.5^{19}\right)$ の模式図に改良を加え, それにさきの大村らの研究を組み合せ，同時に従来膀脱 粘膜に現れるとされた, 乳頭状增殖, 陰窩状增殖, 露胞 形成, 白斑化などの病変を初期病巣の変貌過程に組み込 んで, 第 1，2図のように系統ずけてみた。すなわち何

第 1 図

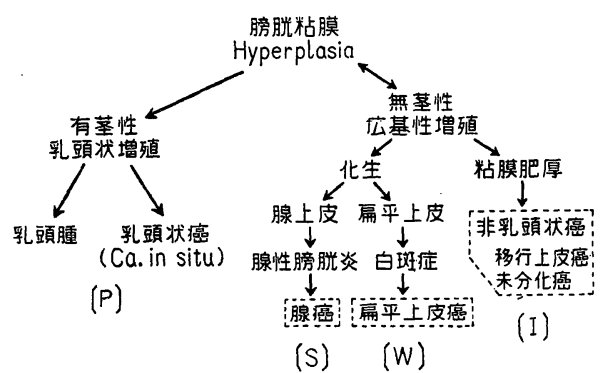

第 2 図 Type of Tumor

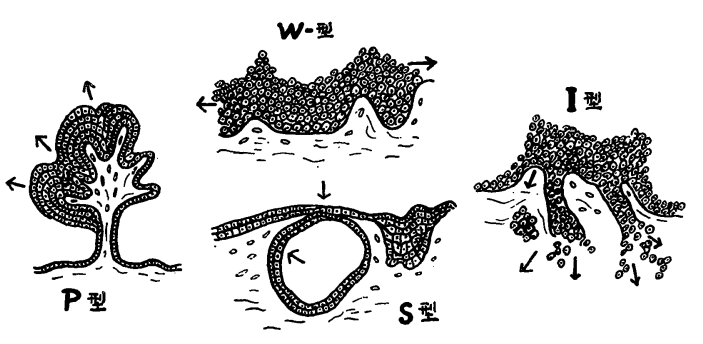

らかの発症機序によつて膀胱粘膜上皮細胞が異常に自律 性の增殖を始めるとすれば，単位面積内では自ら有茎性 および無茎性の 2 万向に発育することになり，それらが それぞれの周囲環境と組織発生の基盤の上で，ある場合 には移行上皮癌, 腺癌, 扁平上皮癌あるいは未分化癌に 之, 所謂癌化増殖して行く可能性があるわけである. し たがつて詳細な内視鏡所見と生検像とを組み合せかつそ の経過をも組入れて検討すれば，初期病像として出現す るであろう粘膜の肥厚, 增殖傾向などの癌化過程へ腫瘍 の発育形式と腫湯細胞型の組合せによる判断がある程度 可能となる. かくして早期膀胱癌を大別分類したのが第 
2 図のごとき 4 型である

（1） $P$ 型（papillary type）：膀胱腔内に向つて, 乳頭状に增殖し, 膀脱鏡では孤立有茎性, 周团粘膜とは 関連性のない型で，病理組織学的には樹枝状の細い間質 の表面を数層の紡錘型ないし楕円型の胞体，円形ほ心゙同 大の核をもつた細胞が重積発育した像を示す所謂有茎性 乳頭状発育型であり, 腫瘍細胞型としては, grade I 度, 時に II度で比較的均一な細胞の集簇であることが多く， stage にすれば IS 程度である。

（2） $\mathrm{S}$ 型（surround type）：無茎性で膀胱鏡的に は小晓胞の集簇あるいは露胞状浮腫状の限局病巣で, 病 理組織学的には，円型あるいは類円型の胞体で境界の明 かな細胞が 3 ないし 4 層に重積した移行上皮が增殖しつ つ陰窩状に陷凹発育するか，または腺腫状に囊胞壁を形 成しつつ上皮下に下降埋没されるいわゆる囊胞状增殖あ るいは陰窩状增殖の像を示す初期病像である. grade は I 度ではあるが， stage は大体 I.S. 抢よび $T_{1}$ までで， 時の経過によつてはあるものは腺癌にまで進展する可能 性を含む。

（3） $\mathrm{W}$ 型（wide type）：膀胱鏡的に $\mathrm{P}$ 型とは異り 乳頭状発育を示さず，周囲粘膜との境界やや不鮮明に僅 かに隆起し，比較的平坦な横軸に增殖を示す限局性の初 期発育病巣である。易出血性，表面微細顆粒状ないしは ビロード状（数の子状）の所見を呈し，病理組織学的に は類円型やや大型の胞体とクロマチンに富む核をもつた 細胞集団が，基底細胞層そ主軸に比較的正しく数層に累 積増殖する傾向をみる初期像である。無茎性広基性であ り，間質での血管は比較的少い，grade は概して II度程 度のものが多いが，時には当初より定型的な上皮内癌と して大型異型性の細胞の出現，大小不同，核分裂像があ り，吕度の所見を示すことも少ない。したがつてさらに grade の進展状態によつては stage は $\mathrm{T}_{2}$ までに進展 している可能性も予測出来る。またこの発育型は本来の 移行上皮細胞から逸脱して扁平上皮化生ないし白斑化を 呈することも多く，これを基盤として扁平上皮癌にまで Anaplasia を示す可能性がある。 かかる変化はどちら かと云光ば膀胱壁の随所飞潜在的飞存在し，異所再発， 局所再燃の原因となりやすく，一種独特な発育型と云兄 る。

（4） I 型 (infiltrate type)：前述の P 型とは対照的 な性格で無茎性むしろ広基性，境界不明瞭な半球状ない 乙塊状の初めから浸潤増殖傾向を示寸発育型で，表面顆 粒状，所によつては乳嘴状，早期より出血性，壊死性で
ある。病理組織学的には胞体は境界不明瞭な大型類円型 ないし紡鍾型で，核は大小不同，クロマチンに濃淡があ り，配列も不規則，処々に明かな核分裂像が 散見され grade では度ないしIV度，最初から未分化細胞型の発 育傾向をとり，早期に基底膜の破壊像がうかがわれ経過 もすみやかである。 stage では $\mathrm{T}_{2}$ の範疇にまで進展す ることが多い。すなわち最も抵抗性が少く，容易に発育 可能と考兄られる膀胱腔内に向つては增殖しないで，む しろ当初から基底膜, 筋層を破つて浸潤発育しょうとす る性質であり，これこそいわゆる癌独特の病像を早期に 示す発育型とみることも出来る.

以上の $\mathrm{P}, \mathrm{S}, \mathrm{W}, \mathrm{I}$ 型の 4 型の頻度を最初の病像から過 去 5 年間観察し得た 48 例についてみると (第 5 表), 早期

第 5 表 腫瘍型別（電気焙灼）

\begin{tabular}{cc|c|c||c|c}
\hline & & 例数 & \multicolumn{1}{c||}{$\%$} & \multicolumn{2}{|c}{5 年生存率 $\%$} \\
\hline $\mathrm{P}$ & 型 & 31 & 64.7 & 26 & 83.8 \\
\hline $\mathrm{S}$ & 型 & 6 & 12.5 & 3 & 50.0 \\
\hline $\mathrm{W}$ & 型 & 7 & 14.5 & 2 & 28.5 \\
\hline $\mathrm{I}$ & 型 & 4 & 8.3 & 1 & 25.0 \\
\hline \multicolumn{2}{c|}{ 計 } & 48 & 100. & 32 & 66.4 \\
\hline
\end{tabular}

膀胼癌として最も普通の型とされる P 型が31/48（64.7 \%), 次いでW型は $7 / 48(14.5 \%), \mathrm{S}$ 型は6/48(12.5\%)， I 型は $4 / 48$ （8.3\%） である。すなわち初期膀胱癌で は，乳頭状有茎性腫瘍 $\mathrm{P}$ 型が最も多いことはここでも明 かであるが，一方最初から未分化一浸潤像を示す病型の 存在も認㧹る。次にこの 48 例について無選択的に電気 燒灼術を施した場合のそれぞれの 5 年生存率をみると， $\mathrm{P}$ 型は26/31（83.8\%）で最も良好な成績を示し， $\mathrm{S}$ 型 は $3 / 6(50.0 \%), W$ 型は $2 / 7(28.5 \%), I$ 型は $1 / 4(25.0 \%)$ と なる、P型が意外と良好で，逆にＩ型がはなはだ不良な この成績は，たとへ早期病像で，腫癔細胞型が単一であ つたとしても，それぞれの発育型によつて予後を全く異 にすることを示唆すると同時に，生検においては，たと へ表在性の細胞の集積から grade のみが院みとられる としても，これに上述のごとき発育型の如何を加味すれ ば，来るべき浸潤の度合いをある程度予測し得る可能性 があり，grade 臨床上可成り有力な資料とすることが 期待できると考劣る．すなわちP 型で grade III 症例を みた場合，grade III として大きな手術侵襲を加觉るより， P 型としてより保存的治療法が潠択され，また I 型で 
grade II の場合は，徹底した術式を選択すると云う様な 判定が可能となろう.

\section{Brown-Pearce 腫瘍による実験的膀胱腫瘍}

前述のごとく人の早期膀胱癌の治療成績拉よび初期病 像の解析から, 早期膀胱癌の診断乱よび治療法の選定の 規準には，初期発育型を加味した grade の判読が役立 つであろらことが示唆されたのであるが，その成績に基 き，さらに膀胱壁表層または深層で，low grade の腫 瘍細胞が発育し始めた場合，それが stage として如何に 進行するか，またこれらが增殖する場合，粘膜側（膀胱 腔）に向つて発育するのか，それとも反対に筋層を通じ て浆膜側に向つて進行する傾向が強いか，すなわちその 局所の增殖発育の potency はいずれにあるか, 動物実 験により追求し，grade と stage に関する考察の裏付け とすべく以下のごとく検討した .

すなわち可移植性の Brown-Pearce 腫瘍を家鬼膀胱 壁に直接移殖し，接種直後の low grade の状態からそ の経日的な進展に伴う変貌を, 腫汮細胞自体の発育方向 および腫瘍周囲組織（結合織あるいは筋層）の態度を中 心として追求した。

a）実験材料ならびに実験方法

実験には体重 $2.0 \mathrm{~kg}$ 前後の健康な栄養可良な白色雄性 家鬼を使用した。移植に使用した Brown-Pearce 腫瘍 は，すでに教室の東野 ${ }^{34)}$ ，白神 ${ }^{35)}$ が報告した累代移植腫 瘍である，その類代移植法の概略は，睪丸移植後，平均 2 週間を経過した頃，睪丸拉よび精索に明かに腫瘍が触 知され，るいそう著明となつた家鬼を無菌的に開腹し， 大網リンパ節転移の腫瘍塊より壊死部は除外して，淡紅 色，飴色の部位を切り出し，これを直径約 $0.5 \mathrm{~cm}$ の腫瘍 片に細切して，同量の生理的食塩水を加宇，“い添”な しの homogenizer に電動装置（高島製）用いて $(1,000$ r.p.m) homogenize して，無菌的経皮的に左右梓丸実 質内に $1.0 \mathrm{cc}$ づつ注入することによつて容易に累代接種 を継続したものである。

私の試みた膀胱壁移植実験方法は，前述の累代移植と 同様に homogenize された材料に，さらに同量の生理 的食塩水で稀粉混和後, 無菌ガーゼで濾過した Tumor Emulsion を接種材料とした。家鬼膀胱壁内接種の要領 は, Pentobarbital natrium 50mg (1 cc) の筋注麻酔 により抑臥位で，無菌的に開腹，導尿にて排尿させた 膀胱を創外に脱転した後, 第 6 表のごとく注入部位を 4 カ所に分けて接種を試みた。すなわち総計 35 羽の対象に おいて，接種部位を膀胱頂部と三角部の 2 カ所に分け，
第 6 表 接種家鬼

\begin{tabular}{|c|c|c|c|c|c|c|}
\hline \multirow{2}{*}{\multicolumn{2}{|c|}{$\begin{array}{l}\text { 接種 } \\
\text { 部位 } \\
\text { 屠殺 } \\
\text { 期間 } \\
\end{array}$}} & 項 & 部 & $\equiv$ & 部 & \multirow{2}{*}{ 計 } \\
\hline & & \multicolumn{2}{|c|}{ 粘膜下筋肉内 } & \multicolumn{2}{|c|}{ 粘膜下筋肉内 } & \\
\hline 1 & 週 & 3 & 4 & 3 & 4 & 14 \\
\hline 2 & 週 & 2 & 3 & 3 & 3 & 11 \\
\hline 3 & 週 & 2 & 3 & 2 & 3 & 10 \\
\hline \multirow{2}{*}{\multicolumn{2}{|c|}{ 計 }} & 7 & 10 & 8 & 10 & \multirow{2}{*}{35} \\
\hline & & \multicolumn{2}{|c|}{17} & \multicolumn{2}{|c|}{18} & \\
\hline
\end{tabular}

その二つの部位でさらにそれぞれ，粘膜直下接種（浅表 層発育)，および筋層内接種（深層発育）に分村，計 4 群に大別した，部位別，屠殺期間別の 接種家鬼数はそ れぞれ表 6 のごとくである. 粘膜直下接種はあらかじめ 準備した $1 / 3$ 皮下針をつけたマントー 注射器で，Tumor emulsion $0.1 \mathrm{cc}$ 浆膜，筋層を貫いて粘膜下に打い て境界明瞭な膨疮を作るごとく刺入し，一方筋層内に は同様に直径 $0.5 \mathrm{~cm}$ の小結節を作るように注入し，筋 肉，皮膚縫合を施して創を閉じた。感染防止としては， Tetracyclin 30mgを術直後に筋注した. 接種後は 1 週, 2 週， 3 週後にそれぞれ層殺し，剖検により，膀脱粘膜 および膀胱壁に㔚ける病巣の遂日的変貌と同時に転移の 有無を肉眼的に観察し，さらに移植腫瘍部位を，周囲 の健常部位を含めて剔出した後，10\%ホルマリン液に固 定，パラフイン切片のStep section を作製，H.E染色， Vangieson 染色, Asan-Mallory 染色，時に Pap 氏鍍 銀染色を施して，Brown-Peace 腫瘍の発育，周团組織 の関係について検討を加えた。

b) 実験成績

1）頂部接種群所見

（i）粘膜下接種群（浅表層発育群）

接種 1 週間後層殺群（3 羽）は，頂部の接種部位に一 致して直径 $2.0 \times 1.5 \mathrm{~cm}$ あでの境界明瞭な半球状に突出 した. 充実性弾力性の暗赤色表面微細顆粒状の移植陽性 腫瘍を明らかに認める (第 3 図右).周囲の粘膜は㱀壁に 富み，腫瘍の浸潤は肉眼的には全く見られない。またそ の部に一致する浆膜側を変化を認めないまたこの時期 では，膀胼周囲，あるいは腸骨リンパ節などには，転移 巣は認めない。病理組織学的には（第 4 図）,粘膜上皮は 僅かに增殖し，その表層は空泡変性を見る。粘膜直下に は浮腫を認め, 結合織の中には, 胞体の大型で多角形, 核はクロマチンに乏しい境界の明かな腫瘍細胞集団が限 
第 3 図 粘膜下接種，第 1 週後右（項部）左（三角 部）
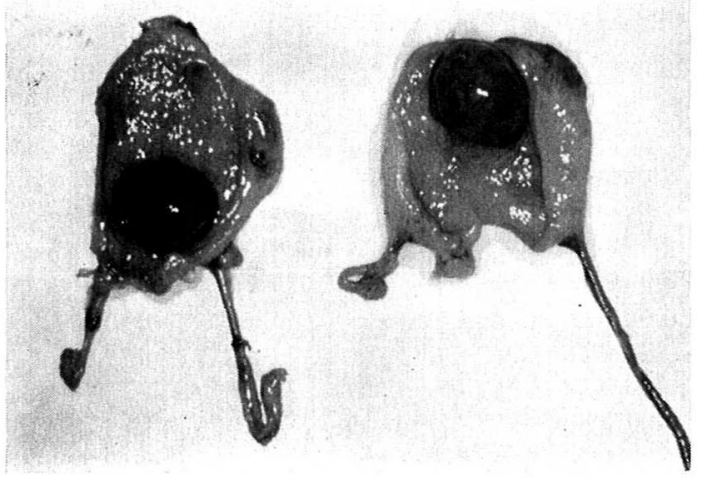

第 5 図 項部粘膜下接種第 2 週後著明に半球状に 突出

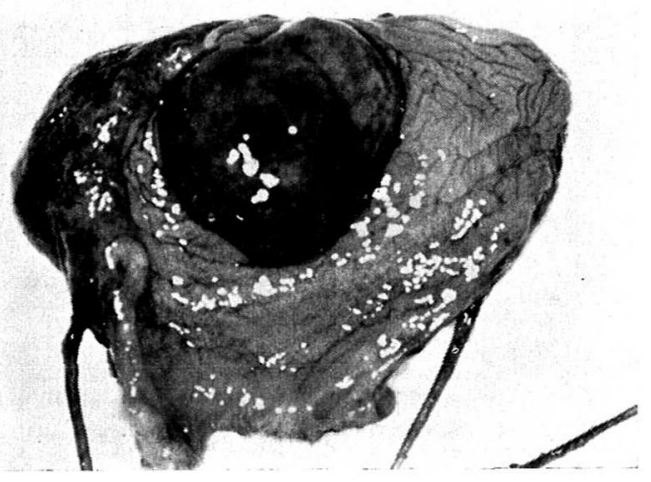

第 7 図項部粘膜下接種第 3 週後

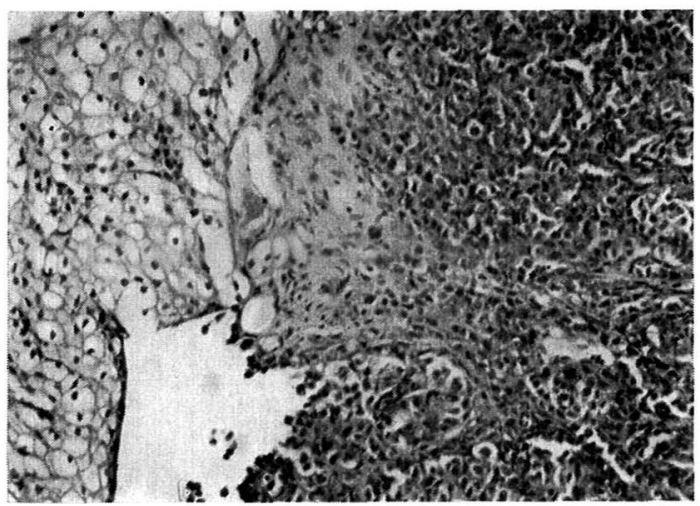

第 4 図 項部粘膜下接種 (IW) 腫瘍細胞の限局性 集簇像

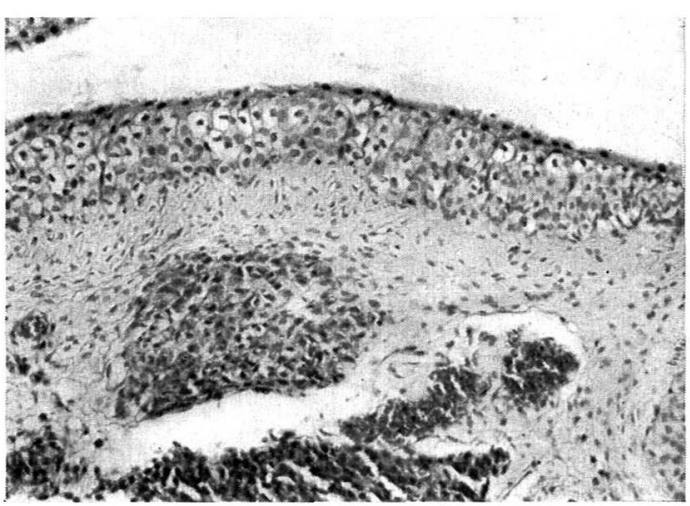

第 6 図 第 5 図の組織像笳層での浸潤阻止

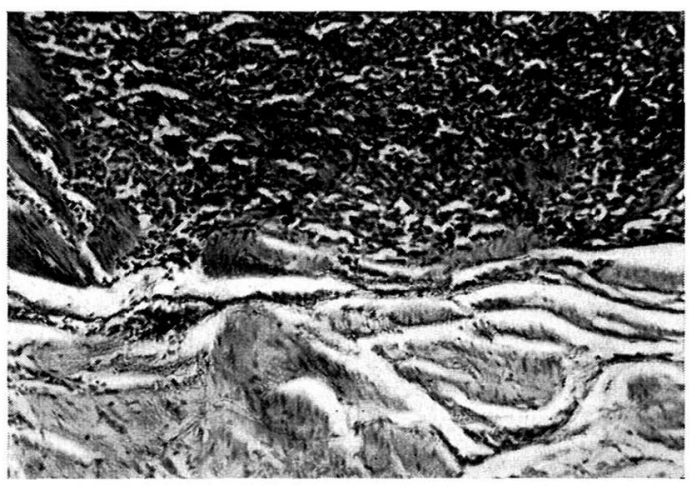

第 8 図 項部筋層内接種第 1 週目

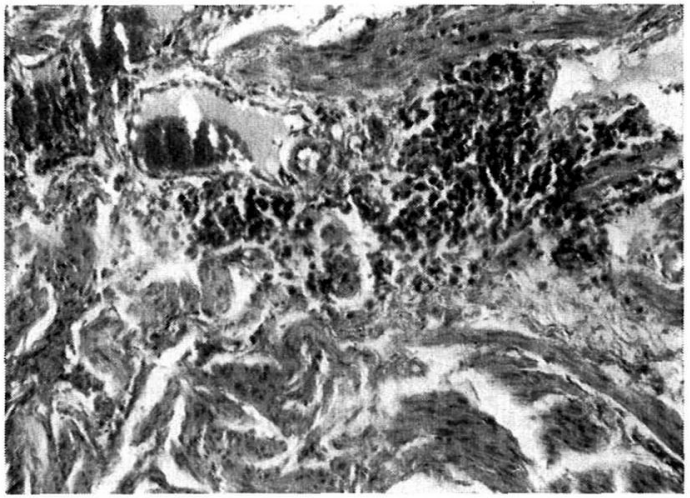


第 9 図 項部筋層内接種第 2 週目

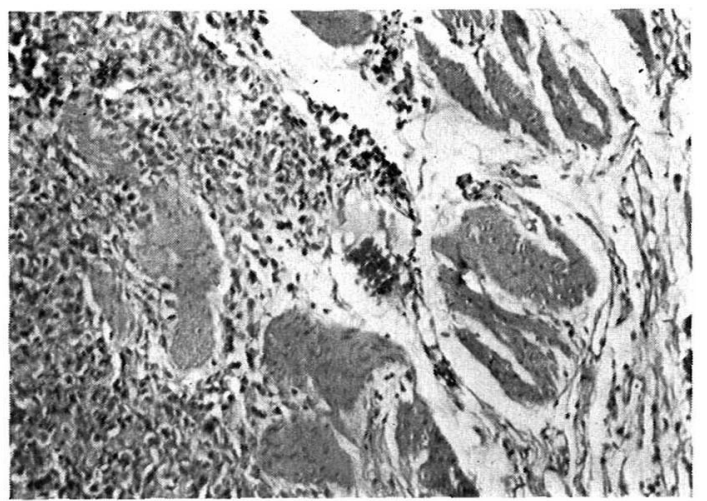

第11図 三角部粘膜下接種第 1 週後

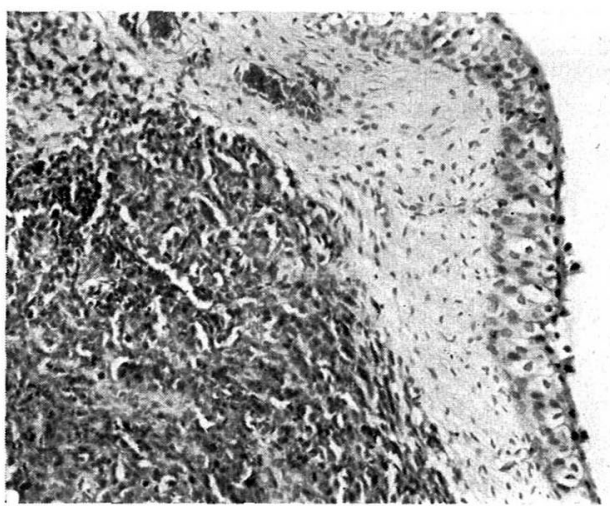

第13図 三角部粘膜下接種第 2 週後浸潤は筋層で阻 止

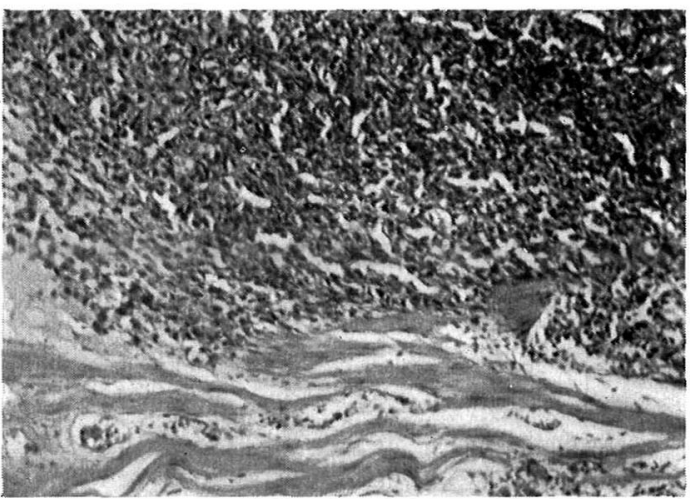

第10図 項部筋層内接種第 3 週目漿膜側飞到達

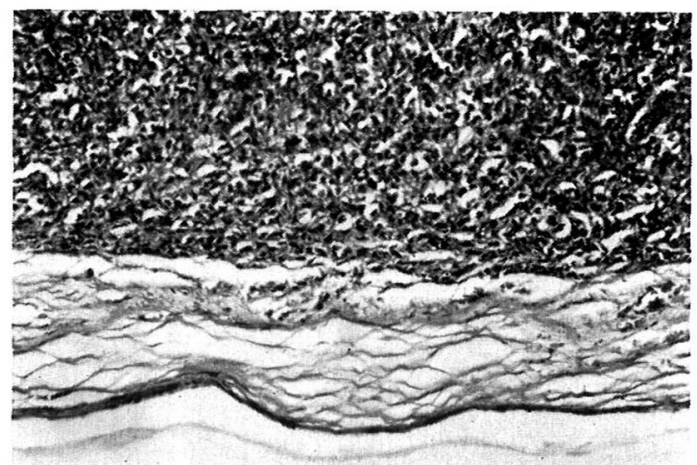

第12図 三角部粘膜下接種第 2 週後

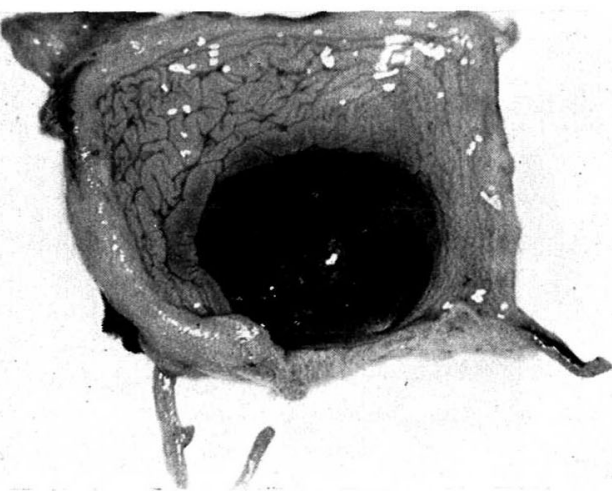

第14図 三角部筋層内接種第 1 週後 (漿膜側)

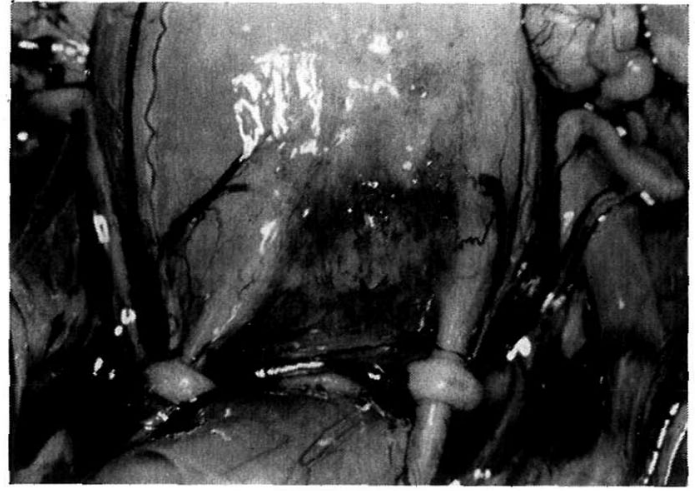


第15図 三角部筋層内接種第 2 週後

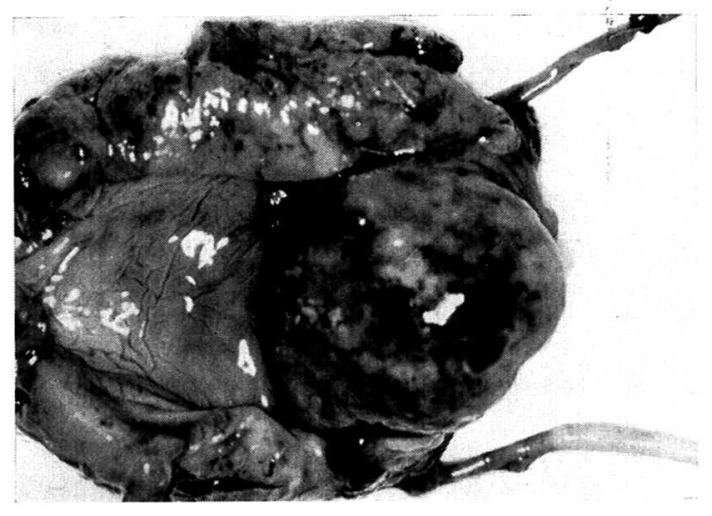

第17図三角部筋層内接種第 3 週後(完全に腫癔化)

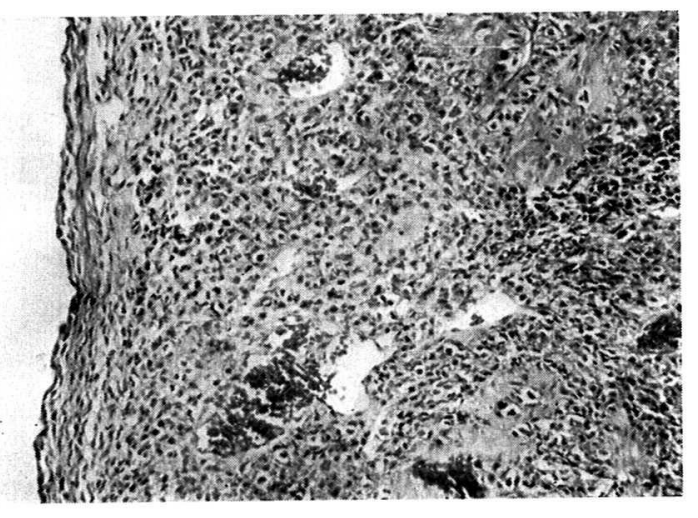

局性に見られるが、いまだ周囲には全く浸潤を示さない， 接種 2 週後屠殺群（第 5 図）は, 腫瘍は遂次増大し, 大きさは $2.0 \times 2.5 \mathrm{~cm}$ 半球状に膀脱腔内に著しく突出 し, 表面光沢を有して, 緊張性, 暗赤色ではあるが, 周 囲粘膜との境界は明かである。この時期においても浆膜 面は平滑で僅かに細血管の充盈をみるのみである，病理 組織学的所見では, 粘膜下にはやや小型の細胞間境界の 不鮮明な腫瘍細胞が, 粘膜直下に著しく增殖し, 表層に 向つて浸潤像を呈して来る。核は大小不同, 核分裂像も 散見する。しかし筋層では明らかな境界をもつて腫瘍綀 胞の浸潤は阻止されている(第 6 図)．

第 3 週後屠殺群では，腫瘍は著明に增大し大きさ直径 $2.5 \times 3.0 \mathrm{~cm}$ 周囲粘膜に発赤浸潤を伴い, 腫瘍の表面は 暗赤色ところによつては壞死性であり黄白苔を附し, 易 出血性である。頂部浆膜面にも球状, 腫湯状に突出し, 細血管の走行を認め, この時期では, 腸骨リンパ節, あ
第16図 三角部筋層内接種第 2 週後筋層の断裂

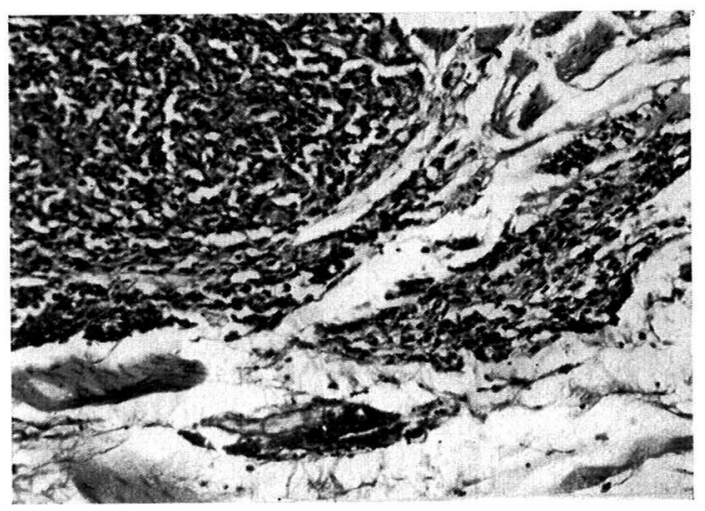

るいは後腫膜リンパ節に散在性に小亘大の転移栄を見る ものもある。病理組織学的には, 上皮は空胞変性, 扁平 上皮化生を伴つて著明に增殖し（第 7 図),多角形ないし 類円型の大型の腫瘍細胞は, 粘膜下まで浸潤し, 一部は 粘膜上皮の剥離，脱落を招来している．また処によつて は, 小出血巣や壞死巣が見られる。この時期では筋層内 にる腫瘍細胞の増殖が随所に見られるが，浆膜側までは 完全に到達しておらない。

(ii) 筋層内接種群 (深層增殖群)

筋層内移植 1 週間後の屠殺家鬼では, 膀脱壁移植部は 境界明膫に大きさ $2.0 \times 1.8 \mathrm{~cm}$ と膀脱腔内に半球状に膨 隆して, 淡紅色, 表面平滑で光沢を有し, 充実性でやや 硬い, 膀胱壁は肥厚して浆膜面わずかに突出し, 浆膜に は浮腫および細血管の充盈が見られる. 病理組織学的に は (第 8 図), 浮腫性の節層内に㧄いて, 胞体の不明䐲な クロマチンに富むやや大型の類円型の核をもつた腫瘍細 胞が集簇して認められ, 腫瘍細胞に近い筋層は, 融解像 が明らかてみられると同時に，隣接する細静脈の㹡張う つ血が認められる。

第 2 週目の屠殺群では, 腫瘍は直径 $2.0 \mathrm{~cm}$ 内外球状充実 性に著しく増大して, 頂部を大きく占め, 表面鼣璧に乏し く, 膀胱壁は肥厚すると同時に浆膜側にも僅かながら充 血性の膨隆突出を認める。早いものでは周囲リンパ節に 転移像をみるものも市る。病理組織像では, 筋層の中飞 增殖した移植腫瘍細胞が踈開した笳層を王排しつつ浆膜 面に向つて浸潤する像が認められる。しかしこの時期で も腫瘍細胞は筋層を完全には貫通していない(第 9 図).

第 3 週目屠殺群では，接種部位は著明に腫脹し，大い さ3.0 $2.5 \mathrm{~cm}$ 周团粘膜への浸潤は強く, 腫痬の表面は暗 
褐色, 壊疸性で随所に黄苔を附し, 硬度はやや硬く, 浆 膜面にも膨隆突出して暗赤色を呈し, 膀胼周囲リンパ節 に小豆大ないし小指頭大の転移を多数認め, また後腹膜 腔にも球形小豆大の転移巣を多数認める. 病理組織学的 には(第10図), 多角形, 胞体のpや不明瞭な大小種々の類 円形の核をもつ腫瘍細胞が筋層を完全に貫通して浆膜直 下に到達して緻密に集簇增殖する像を認め，筇線維はむ しろ萎縮性断裂が瘢痕的にみられる。またその周囲の血 管周囲リンパ管には，リンパ行性転移像が散見される。

2）三角部接種群所見

（i ）粘膜下接種群（浅表層発育群）

接種 1 週間後屠殺群では, 接種腫瘍は直径 $2.0 \mathrm{~cm}$, 半 球状, 境界明らかに移植陽性を示し, 周囲粘膜は平滑, 軽度浮腫性であるが，発赤浸潤はいまだ見られない，表 面の性状は頂部接種群の 1 週目とほડ゙変りはないが（第 3 図左),浆膜側は細血管の充盈と共に紅斑, 浮腫を認め るところもある. 病理組織学的には (第11図), 粘膜上皮 は一部空泡変化を見るのみであるが，粘膜下にはびまん 性に浮腫が認められ，その直下にはクロマチンに富む類 円形ないし多角形の腫瘍細胞が塊状をなして集簇してお り，その細胞の一部は粘膜下に向つて進展する像が明か に見られる。

第 2 週目では（第12図）,腫瘍はさらに増大して，直径 $2.5 \mathrm{~cm}$ 以上となり三角部の大部分を占め, 著明に半球状 に突出するが，周囲との境界は明膫で表面は暗黒色，壊 死性で一部に白苔を附着する。硬度は硬く, 僅かに弾力 性易出血性である。浆膜側は中等度に膨隆して充血性, 周囲組織との軽度な線維性癒着を認める. 病理組織学的 には, 胞体の境界不明瞭な, 核質に富んだ腫瘍細胞が著 明に增殖して, 粘膜直下にまで充実性に発育し, 上皮は 菲薄で全般に空泡変性が目立つて認められる。筋層は散 在性に腫湯細胞の浸潤をみるところもあるが，概して浅 表筋層では浸潤は阻止された像を示している(第13図)。

第 3 週目屠殺群では, 腫瘍は直径 $3.0 \mathrm{~cm}$ 程度に著しく 增大し, 周团粘膜も発赤浸潤性で, 腫瘍との境界は不明 瞭となり，表面は凹凸不平で，らつ血性，一部には強い 壤死部がある。膀胱壁は肥厚して, 殊に三解部は腫瘍の ために判然とせず，浆膜側も腫瘍の浸潤強く，浮腫性癒 着を認め, 黄白色の苔を附着する。膀胱周囲のリンパ節 は, 小豆大, 数ヶ腫脹し, 明らかに腫瘍細胞が筋層を貫 いて浆膜側にあらわれた像が見られる。病理組織学的に は, 核質に富んだ大型腫瘍細胞が粘膜直下まで著しく充 実性に增殖して粘膜上皮は高さを增し, 空泡変性ないし
扁平上皮化生を認めるとこちすらある，筋層は增殖した 腫瘍細胞のために疎となり, 筋層間をやや小型の腫瘍細 胞が浸潤して，筋層を貫通する像がみられる。一部では 既に腫瘍細胞が浆膜側に到達するところるみられる。

(ii) 筋層内接種群（深層增殖群）

接種 1 週間目屠殺群では, 腫湯は揊指頭大に膀胱腔内 飞突出增大して, 表面は発赤, 粘膜面の壞死白苔を認 め, 硬度は弾力性軟, 一部易出血性である。周囲の膀胱 粘膜は浮腫状, 細血管充盈して境界はやや不明膫之なつ ている.膀胱壁ことに三角部は肥厚して浆膜側は発赤, 浆膜下浮腫, 細血管が充盈して一部明らかな限局病巣を 認める (第14図). 病理組織学的には, 粘膜下にはな初浮 腫を認め, 境界明膫な胞体の少い核の濃染する腫瘍細胞 が集簇性に認められるが, 筋層ではすでに集簇腫瘍細胞 は一部の筋束を疎に開大して，その筋層間に間質性浮腫 を随所認める。

第 2 週目屠殺群では, 著明に膨隆する黒赤色, 壊疽性 球状の腫瘍は, 直径 $3.0 \mathrm{~cm}$ 内外までそなつて三角部を完 全に腫瘍化し, 周辺部は充盈性の平坦な膀脱粘膜に移行 する．頂部は僅か浮腫性であるが平滑で光沢を有する にすぎない（第15図)，膀胱底部，後壁は著明に胞厚し て, 浆膜面にも赤褐色やや凹凸ある腫湯の突出が見られ る. 三角部のリンパ節は, 米粒大より小豆大に腫脹し, 浆膜の一部と連絡する。病理組織学的には, 紡鍾形ない し類円形の核をもつた細胞間境界の不明膫な腫瘍細胞集 団は，粘膜上皮下まで增殖し，上皮は平滑ではあるが， 一部壊死に陥る像がみられる。筇層は疎になり, 腫瘍先 進部は筋層を貫通せんとする部位が多く，浆膜にも明ら かに到達した腫瘍細胞がみられる.筋層は浮腫断裂を認 め筋線維の菱縮がみられる (第16図).

第 3 週目屠殺群では, 接種腫瘍は著しく増大して大き さ $3.0 \times 4.0 \mathrm{~cm}$ で膀胱三角部はもちろん, 膀胱腔の半ば を占居し, その表面は凹凸不平, 所々に白色の壊死性苔 を附着し, 一部は暗赤色出血性であり, 硬度は軟で腫瘍 全体は扼弱となり, 周囲粘膜との境界はやや不明瞭とな つている. 頂部は浮腫性粘膜下出血巣を認める。膀胱壁 は著明に腫大肥厚し浆膜側にも腫瘍の膨隆があり, 静脈 の怒張が目立つ, この時期では, 膀胱䅡部, 三角部, 尿 管附近のリンパ節は多数腫張して認められる。また腸骨 リンパ節や後腹膜にも点在性に小指頭大の腫瘍転移像が みられる. 病理組織学的には, 定型的な腫瘍細胞が明ら かに增殖発育を示し, 粘膜直下にまで拡大進転して, 上 皮は剝離，一部は多層性を示すが，大部分の上皮は壊死 
に招ちいつている，笳層はかかる腫瘍瘍細胞の急速な発 育によつて疎となり，腫瘍細胞は完全に筋層を集簇性の まま貫通して浆膜下にびまん性に浸潤増殖を示している (第17図).

\section{3）実験的移植膀胱腫瘍小括}

（i）粘膜下 (浅表) 接種群と筋層（深層）接種群と の比較

接種後 7 日目まででは, 腫瘍細胞は両群共に接種部 位に一致して，全例が移植陽性としと着床状態を示し， low grade での增殖を開始する以前の状態に止るが，こ の時期では粘膜面に向つての及剅隆，突出像を示す傾向 にある。第 2 週目となると，Brown-Pearce 腫瘍の特異 性を発揮する。第 2 週目の浅表接種群では，頂部と三角 部との部位別の差が多少出て来るが (後述), 增殖進展 の方向は，共に発育の容易な抵抗の少い粘膜下層に向い 堌殖する傾向を示し，抵抗のある筋層では，浸潤を阻止 する傾向がみられる，從がつて腫瘍は周囲粘膜とは境界 明膫な半球状に突出し, 人膀胱癌の $\mathrm{P}$ 型に類似する外観 を呈する。一方深層内接種群では，第 2 週目で，周囲の 筋組織を疎開しつつ, 逐次筋層内に浸潤拡大する傾向が 目立つている。第 3 週目では，両群共に腫瘍は著明に発 育するが，浅表接種群では筋層は踈になり，腫痬細胞の 浸潤する部位もみられるよらになるが，総じてなお浸潤 を阻止せんとする状態である。しかし深層内接種群で は，容易に筋層を貫通して浆膜面まで到達しており， さらに膀胱周囲のリンパ系にも転移巣をみる。

以上の所見から接種後 2 週目では，浅表接種実験で, 臨床例の早期病像の $\mathrm{P}$ 型， $\mathrm{S}$ 型の発育型式に類似してお り，たとへ grade が，林度を示して来ても， stage は $\mathrm{T}_{1}, \mathrm{~T}_{2}$ までの像ということになる。すなわら早期癌で grade の進行した場合でも， stage が意外と浅表浸潤像 に止ると云う結果は，膀脱に拈いて，腫瘍細胞が low grade の場合は, high stage 飞進行する可能性の少い こと，また抢そいことを実証する形態学的な根拠となろ う。一方深層接種群では，早期より直ちに筋層内に向つ て発育を始め, 粘膜側へは比較的進展が少い傾向がある。 grade 子悪く stage も $T_{2} T_{3}$ となり易く，臨床例の早 期病像のI 型あるいはW型に相当するもので，早くから 浸潤癌としての性格を帯びて来ることを示す。殊に 3 週 目には，浅表，深層ともに臨床例の grade II, IV, stage で $\mathrm{T}_{3}$ の所見を示して来る。すなわち Brown-Pearce 腫 瘍の接種実験において，接種部位の深さでは，浅表接種 群は早期癌の grade, stage の臨床的意義につき示唆す
るものを得，深層接種群では，はじめから臨床上の所謂 浸潤癌の像を呈することを認めた。

(ii) 頂部接種群と三角部接種群との比較

接種後 1 週目では，両群は接種局所における腫場細胞 の定着，增殖開始期に相当するので，部位別での格別の 差は肉眼的にも病理組織学的にも見られない。 2 週目 になると三角部接種群は，頂部接種群に比して，発育度 （大きさ，浸潤度共に）はややまさり，三角部の大半を 占め両側尿管口は判然としなくなる。浆膜側において も，血管充盈，浆膜下出血，腫瘍浸㵎が認められ，この時 期では頂部の場合はいまだ筋層を腫瘍細胞が貫通してお らないにもかかわらず，三角部接種腫瘍は，すでに浸潤 を認め, 人膀胱癌の $\mathrm{T}_{3}-\mathrm{T}_{4}$ に一致する所見である。す なわち実験的移植膀胱腫瘍では，三角部での腫瘍の発育 は胆癌宿主にとつて甚だ不利な事態であることを示唆し ている。

3 週目に预いては，両群共に增殖が著しいが，とくに 三角部接種群は，粘膜下（浅表）接種と筋層内（樑層） 接種の区別もつか奴程に病変が拡大し，多くの転移巣を 認め, 臨床例の浸潤癌に一致する所見である。すなわち この所見も三角部接種群は腫瘍の拡大が急速容易である ことを示すものである.

以上の諸成績の対比から B-P 腫瘍の移植による実験 的膀胱腫瘍では，粘膜下（浅表）接種の場合は，頂部で も, 三角部でも 2 週目までが, 人膀胱の早期癌に近似し た所見を示し，筋層内（深層）接種群では，頂部 1 週目 までが，早期癌に相当する成績で，その後の経過では， すべて実験的浸潤癌に進行することを知つた。

\section{IV 総括ならびに考按}

人癌の場合, その最初の病像から直ちに腫瘍のもつ potency，進展拡大の将来性ないし宿主の予後を判定で きる手段が開拓される事が臨床医として最も望ましい。 まして膀胱癌は内視鏡的に早期の病変が肉眼によつて確 認出来るだけに,一層その期待が大きく,過去幾多の研究 がすすめられて来たことは論を待たない，かくて現段階 では, 生検あるいは剔出材料の病理組織像から腫瘍構成 細胞に和ける未分化細胞の占める量的割合により分類す るBroder のgrade 判定法と,一沶では Jewett-Marschal 13) 43) らによる腫瘍細胞の膀胱壁浸潤度を中心とする stage による分類法が重用され，特に最近では stage が予後 の面で重視さるべきであるとの意見が多く，本邦ではも つぱらこれが重視される傾向にある。事実腫瘍の発育進 展の具体的判定資料は stage が主体であつて， stage を 度外視しての予後判定はほとんど考克られていない。し 
かし浸潤度を重視すべしとする考兄の根底となつた研究 資料のほとんどは，主として進行癌により死亡した剖検 材料によるものである．したがつてその成績は群別の統 計的研究として予後の類推的公算を割り出すためには, 甚だ有力な根拠とはなり得るだろうが，その結果は結局 「浸潤度の高いものは，予後不良である.」と云ら至極 当然の結論を示すもので，膀胱癌に乱ける case by case の予後推測には直接関連しにくいことになる，以上述べ てきたことからここで再び強調 したいのは，本症では 常に早期癌と浸潤癌の症例とを明らかに別な category に区分して，その治療成績などを検討すべきであるとい らことである。早期癌の電気焼灼術の成績では Nichols $\& \mathrm{Marschall}^{20)}$ (1956)は 3 年生存率 $89.5 \%, 5$ 年生存率 $82.6 \%$, 市川 ${ }^{21)}$ (1958）の文部省科学研究班（膀胱癌） の綜合成績では 3 年 $72.3 \% ， 5$ 年 $58.3 \%$, Manzon $\&$ Samellas $^{22)}$ (1962) は 5 年87\%, 吉田 ${ }^{23)}$ (1966) は3 年生存 $83.5 \%, 5$ 年 $73.6 \%$ で, 当教室でも早期癌で 3 年 $85.2 \%, 5$ 年生存 $77 \%$ となる。いずれの報告において も，ほぼ一律に良好な成績を示している。

一方浸潤癌ともなると，いずれの報告も治療成績は格 段と不良であり, これは他藏器の浸潤癌の場合と同様で ある. しかし膀胱癌の一つの特徵として, 早期癌で良好 な成績を一見示しておりらがら，決して根治性を得られ ないものが少くないといら事実がある。そこで私は浸潤 癌はしばらく怙き，一応浸潤癌に比べれば根治性の得き すい早期癌の早期病像の予後に結びつく適確な把握が是 非求められるべきであると考えた.

従来膀胱粘膜にあらわれる病変の研究は, 多々ある が，それに記載されている病巣を総括すると， atypical hyperplasia，乳頭状增殖，陰窩状增殖（Brunn 細胞 巣), 囊胞状增殖, 腺状增殖, 䋐毛增殖, 白斑形成あるい は carcinoma in situ などを挙げることが出来る。そ の中でも膀胱全剔除術適用症例の膀胱粘膜の腫瘍周辺拉 よび遠隔部の病像の分析, 検討は癌化過程と関連のあ 初期病像（前癌状態）を追求する上できわめて興味あ る資料となろう。 Eisenberg et $\mathrm{al}^{28)}$ (1960) は84例 の材料飞赫いて Brunn 細胞巣, 乳頭状增殖, atypical hyperplasia, carcinoma in situ の病像を認め, また Melicow ${ }^{29)}$ (1952）は，腫瘍辺緣から 1-3 cmの部に虂 胞あるいは腺形成，扁平上皮化成，上皮細胞巣を認め ること, $\operatorname{Simon}^{32)}$ et al (1962) は，38例の全剔膀胱で atypical hyperplasia, Brunn 細胞巣, 震胞状膀胱炎, carcinoma in situ を89\%に認めたと報告している。一

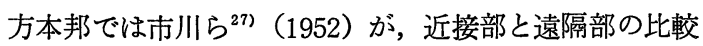
に执いて, 腺性膀脱炎が近接部のみに認められたほか, 他の病巣は, 近接部, 遠隔部で差をみないとしており, また長谷川 ${ }^{25)}$ (1955）も近接部と遠隔部では大差がない ことを認め, 結局膀脱腫瘍では早期に周团粘膜の增殖性 および化生性変化を来たすのではないかと考えている。 以上諸家の報告からみても膀胱癌症例の腫瘍部以外の膀 胱粘膜には，確かにある程度の病変が認められることは 解るが，ただし全剔膀胱の所見から得られた病変だから としても，必ずしもそれがそのまま癌化に結びつく不可 逆性の変化であるとは云えないし，また膀脱周辺の防禦 的現象としての可逆的病変の可能性も多いと思われる. すなわちたとへ遠隔部の膀胱粘膜にある程度の病変があ つても，それが癌化するとは断言出来ないし，無関係だ とも云兄ず, 膀胱癌治療面での再発の問題点ともからみ あつて未解決の問題であると云壳る。結局これらの各病 巣についての研究は, 早期の病変を組織発生および発育 形成をも合せて詳細に分別検討することなく，ただ組織 学的所見のみについて, 関連を求めんとしている処に限 界を生じているとも考えることが出来よう. やはりここ でも初期病変を腫瘍型と発育型を併せて観察し, 将来の 浸潤進展の可能性を推察する方式が検討されて然るべき ものと考光る。さされ Melicow ${ }^{18) 199}(1952 ， 1955)$ は, 膀 脱の上皮性腫瘍発生の段階を系列化して図示し，尿路粘 膜上皮は，環境によつて容易に種々の増殖性変化や化生 性変化を起し，遂には anaplasia によつて癌化を来すと 述べた. ただこの schemaで疑点と考光られるところは， 上皮の增殖肥厚と化生の成立が全く別の系列に和かれて いることである．しかし移行上皮細胞を腫瘍の直接発生 田地とする以上, 先ず最初に認められる病変は, 細胞巣の 重積による增殖変化であるべきで，かかる病巣は正常人 の膀胱粘膜でも，種々の原因によつて可成りの頻度にみ られ，かつ加令につれて多くなる傾向がある (Hexheimer ${ }^{30)}$, Fagerstrom ${ }^{31)}$ ) のので，この事実は增殖性変化が 必ずしも不可逆性の anaplasticな癌化過程をとるとは限

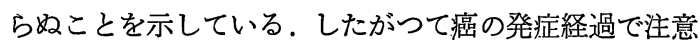
すべきは，增殖性変化の次に来るべき有茎性または無茎 性広基性の 2 方向に大きく分れる進展である.この段階 で始めて腫瘍としての性格が論じられることになろう。 すなわちごく初期の病巣は, 膀胼では移行上皮型ではあ つても，それより以後の発育型式は，決して一型式では ない. そこで私は Melicow ${ }^{29}$ の Schema とは幾分観点 をかえて，第 $1 ， 2$ 図のごとく，膀胱腫瘍発育過程を試 
案図示し，その腫瘍細胞型と発育型で $\mathrm{P}, \mathrm{S}, \mathrm{W}, \mathrm{I}$ 型の 4 型に分類を試みた。I 型, W型は発育, 浸潤が速かである ことはもちろんで, 他臓癌器の浸潤癌同様の拡大進展の 過程をとる悪性腫瘍だと云えるが，P型， $\mathrm{S}$ 型は膀胱癌 に抒いて特徴的とも云光る組織発生であり，他の I,W 型と種々な点で共通に律し得ぬところが多い. 早期癌の 治療法の撰択の上でも充分考慮がはらわねばならぬもの と考える。殊に，この発育型式のそれぞれ異つた早期癌 に，教室に扔いて無差別に施行した電気焼灼術の治療成 績をみると， $P$ 型は $83.8 \%$ ， の成績を得るにかかわら ず，W,I 型が $28.5 \% ， 25.0 \%$ の不良な成績を示した事 実は，腫瘍発育型式でも，無茎性広基性で，grade の高 い腫瘍はたとへ stage が判然としなくても，自ら $\mathrm{T}_{1} \mathrm{~T}_{2}$ の状態が頑推され, grade と stage はほぼ比例するもの で, high grade のものは自ら予後が不良であることを らかがわしめる。すなわち早期癌の診断に際しては, 腫 瘍細胞型と腫瘍発育型を考慮に入れて，膀胱鏡所見およ び生検像を基にすれば，その腫瘍が進展せんとする多能 性を包蔵する性格ひいては stage るある程度看破するこ とが出来, 臨床上役立ち得ると考える，かかる観点に立 ち, 初期病像を分類し, さらにその病像の治療成績を時 日の経過も含めて検討した報告は少い。

私は早期病像の各型に和ける発育浸潤の態度を裏付け るために, Brown-Pearce 腫瘍を膀脱壁に移植する動物 実験を試みた。

従来実験的膀胱腫瘍は，1）発癌物質投与による動物 自然発生癌の研究と 2）動物腫瘍の移植腫瘍作製によ る研究の 2 者があるが，その中で前者は尿路系に腫晹が 出来るかどうかの発癌機序解明の研究方法として有力で あり，後者はすでに腫瘍と認められた腫瘍細胞自体の移 植の可能性，局所および転移巣の形成状態の観察の目的 で有用である。さて膀胱の移植腫瘍の実験は, Wallace et $\mathrm{al}^{37)}$ (1958) が経尿道的に腫場腹水を注入し, その可 移植性を追求したのをはじめ, 加藤 ${ }^{38}$ (1966)は, 吉田肉 腫扣よび腹水肝癌 AH 130の経尿道的移植実験を試み， 正常粘膜での可移植性および移植後の転移について報告

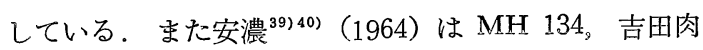
腫および AH 130を腹水および組織片として，それ,ぞれ 径腹的に膀胱内に注入し, 高率な可能移植を得, 詳細に 報告した。また力武 $(1960)^{411}$ は， B-P 腫瘍を膀胱壁に 移植して，その移植可能性のあることを最初に実験し， その腫瘍型は觬様癌の性格で增殖することを報告した。 しかしこれらの移植腫瘍の実験は, 可移植性の有無と転
移の状態についての研究であり，瀶床の早期癌に類似し た形式といら立場でその発育增殖を，移植直後の時期で 詳細に追求せんとした私の研究とは幾分趣きを異にして いる. 私の成績では, 粘膜下浅層接種群の接種後 $1 \sim 2$ 週目に打いては, 腫瘍は膀胱腔内（粘膜側）飞突出增殖 する性格のあることを認めた。これは臨床例に淤ける早 期癌の発育型を追求するのに重要な一所見と思われる。 な扮逆に筋層内深層接種群では, 当初から浸潤癌に類似 する発育を示し, 結局臨床例では, 早期癌とを当初から 明らかに区別して検討する要のあることを実験的にも裏 付けることが出来たと考壳る。もちろん移行上皮より発 生した乳頭状移行上皮癌と B-P 腫瘍では, 組織発生も 形態像も全く異るもので，この両者を全く同一視して考 壳ることは出来ないが，元来，Brown-Pearce 腫瘍は比 較的容易に移植され，急激に增大し，かつ転移もすみや かである性格をもらながら，膀脂壁に移植した場合は， 壁内でもその部位により增殖発育型式は，他の臟器に移 植した場合と可成り趣を異にしている。また，さきの力 武 ${ }^{41)}$ の実験成績でも，移植可能ではあるが，累代移植株 の保在臓器としては，膀羘は適当でないと述べているこ とから，逆に膀胱壁では，腫瘍が比較的限局性に遂次発 育する性格があるわけで，人膀胱癌の grade と stage の関連性を観察する上では, Brown-Pearce 腫瘍は適当 な腫瘍であり,この点からも本実験の成績は十分参考資 料になり得るものと信ずる.

\section{$\mathbf{V}$ 結 論}

膀胱癌の早期例につき治療成績を検討し，また家鬼膀 胱壁内に Brown-Pearce 腫瘍を接種して, 実験的膀胱 腫瘍を作製する動物実験を行ない，主として早期膀脱癌 の腫瘍細胞型の臨床上の評価の方法につき検討を加兄 た。

1）教室における早期膀胱癌は，電気焼灼術および膀 胱部分切除術を通じて，その治療成績は良好である。

2）早期膀胱癌の根治性を高めるためには，当初の診 断において早期癌を，同一增殖形式に一括包含すること なく，腫軥細胞型と発育型式を合せて判定することが必 要である。

3）早期癌の発育型式を, P, S, W, I 型の 4 型に分け て，その頻度，治療成績の分析を試みた。その結果 $\mathrm{P}, \mathrm{S}$ 型は, 真の low grade, low stage であり，W,I 型は早 期であつても, low grade, low stage とは云立ない。

4）Brown-Pearce 腫陽を膀胱壁内に移植実験し，接 種部位によつて, 膀脱内に突出する限局性の実験的膀脱 
腫瘍を作り得た。

5）上記実験的研究で，粘膜下浅層接種群では，1〜 2 週目では，臨床例の早期癌に類似した病像が得られ， この場合, grade が高くても stage が筋層の抵抗により 意外之低い。乙かし筋層内接種群では，直に浸潤癌の経 過をとることが実証された。

6）早期癌では，腫瘍発育型式と腫瘍細胞の grade がまず重視され，その対策が選択さるべきものと考兄 る.

本研究には, 文部省科学研究助成金の補助を受けた。

本論文の要旨は，第55回日本泌尿器科学会総会, 日本 泌尿器科学会第19回西日本連合地方会に招いて発表し た。尚日本泌尿器科学会第20回西日本連合地方会におい て新島教授が膀胱癌の基礎的研究でその一部を報告し た。

稿を終るにあたり, 御指導, 御校閲戴いた新島端夫教 授に深謝するとともに，御援助下さつた大北健逸助教授 に感謝する。

\section{文献}

1) 大村順一, 大北健逸, 田坂純雄 : 日本癌学会記 事, 21回, 179, 昭37。

2）大村順一，大北健逸，大森弘之，藤田幸利：日 本癌学会記事, 23 回, 256 , 昭 39.

3）大村順一：日泌尿会誌，56, 938, 昭 40 。

4) 松村陽右：泌尿紀要，13，185, 昭42.

5）大北健逸：日泌尿会誌，58，938, 昭42.

6) 大北健逸：臨泌, 21, 765, 昭 42 .

7）大北健逸：皮と泌，29，291,昭42.

8) Willis, R.A.: Pathology of tumors 4 th ed 467, 1967 Butter worths.

9）栗原登，高野昭：癌の臨床，11，628, 昭 40.

10) U.S. Public Health Service: National Cancer Institute Monograph, 15, Washington, 1964.

11) U.S. Public Health Service: National Cancer Institute Monograph, 6, 101, Washington, 1961.

12) Mostofi, F.K.: Symposium on cancer of the urinary bladder, S. Karger, N.Y. 1961.

13) Jewett, H.J. and Strong, G.H. J. Urol., 55,
$366,1946$.

14) Jewett, H.J.: J.A.M.A., 134, 496, 1947.

15) 今井環: 癌の臨休, 13, 296, 昭 42.

16) U.I.C.C.: Malignant tumors of the urinary bladder. 1963-1967.

17) 高安久雄, 大田黒和生, 河辺香月 : 癌の臨床, 13. 316 , 昭 42 .

18) Melicow, M.M. and Hollowell, J.M.: J. Urol., 68, 763, 1952.

19) Melicow, M.M.: J. Urol., 74, 498, 1955.

20) Nichols, J.A. and Marschall, V.F.: Cancer, 9, 559, 1956.

21）市川篤二：日泌尿会誌, 49,602 , 昭33.

22) Manzon S. and Sammellas W.: J. Urol., 88, 402, 1962.

23）吉田修：泌尿紀要，12，1261, 昭41.

24) 吉田修：泌尿紀要，12，1375，昭41.

25）長谷川泰：日泌尿会誌, 46,296 , 昭 30.

26）楠隆光, 伊藤泰二, 長谷川泰: 臨床皮泌, 8, 509, 昭29.

27）市川篤二, 辻一郎, 石井澄子 : 日泌尿会誌, 43 , 19，昭27.

28) Eisenberg, R.B., Roth, R.B. and Schweinsberg, M.H.: J. Urol., 84, 544, 1960.

29) Mellicow, M.M.: J. Urol, 68, 261, 1952.

30) Herxheimer, G.: Virchow. Arch, 185, 91, 1906.

31) Fagerstrom, D.P.: J. Urol., 59, 333, 1948.

32) Simon, W., Cordonnier, J.J. and Snodgrass, W.T.: J. Urol., 88, 797, 1962.

33) Masina, F.: Brit. J. Surg., 41, 494, 1954.

34) 東野秀雄: 泌尿紀要, 11,549 , 昭 40.

35）白神健志：日泌尿会誌, 58, 1010, 昭42.

36）新島端夫：西日泌， 31,154 , 昭44.

37) Wallace, A.C. and Hershfield, E.S.: Brit. J. Cancer, 12, 622, 1958.

38) 加藤正和：日泌尿会誌，57，360,昭 41 .

39) 安濃栄一：日泌尿会誌，56, 363, 昭 40 .

40) 安濃栄一：日泌水会誌, 55, 797, 昭39.

41）力武貞之: 久留米医学会雑誌, 23,2611 , 昭39.

$42 ） 三$ 浦忠雄：日泌尿会誌，57，1122，昭41.

43) Marschall, V.F.: J. Urol., 68, 714, 1952.

(昭和44年 8 月11日受付) 